\title{
Introduction of the 2015 Law on Public Investments and Its Effects on Public Sector Accounting in Vietnam
}

\author{
Pham Quang Huy \\ University of Economics Ho Chi Minh City, Vietnam
}

\begin{abstract}
The public sector has a key role to play in enhancing the local goods and services. The Government is fully aware of the fact that Vietnam needs a proper public sector as a product of the state's public policy, which provides high-quality and well-functioning educational, healthcare, or social security systems through the effective management and use of public funds. Those services need investments from them to achieve the objectives set by the official governments or the national programs annually. This paper introduces the content of law on public investments in Vietnam which will be effective in the year 2015. It employs an overview of this law and investigates the effect of public investment in infrastructure on economic performance in the case of Vietnam. Moreover, results suggest that there may be some effects on public sector accounting in Vietnam. This study compares between the 2015 law and accounting in non-business organizations in some aspects for clear clarification.
\end{abstract}

Keywords: accounting, public sector, public investment, public service

\section{Introduction}

Vietnam Public Investment Law 2014 No. 49/2014/QH13 dated June 18, 2014 with 63 pages shall be valid from January 1, 2015. It has decided to only pay outstanding debts in capital construction arising before its time. At the same time, it encourages organizations and individuals to make direct investments or investments in the form of public-private partnership for socio-economic infrastructure and public-service provision projects (Nguyen, 2012). This law is promulgated to promote drastically the operation of planning and investment. Especially, the Vietnam Public Investment Law 2014 institutionalizes the process of determination on investment policy (Vietnam News Agency, 2015). According to leaders of the Ministry of Planning and Investment, this law will contribute to completing and creating a uniform legal system, synchronized in all phases, activities, and the public investment management process of all public capital investment sources (Pham, 2013).

Besides, the law also details some public investment sectors, such as: investment in socio-economic infrastructure programs and projects; investment made to serve the activities of state agencies, non-business units, political organizations, and socio-political organizations; investment in support of the provision of public-utility products and services; and state investment in projects to be implemented in form of public-private partnership. Depending on their importance and size, public investment projects shall be classified into national important projects: Group-A, Group-B, and Group-C projects (Quang, 2014). A national important project is an independent

Pham Quang Huy, lecturer in Public Sector Accounting Division, School of Accounting, University of Economics Ho Chi Minh City. Email: pquanghuy@ueh.edu.vn. 
investment project or a cluster of closely linked works financed by public investment funds of VND 10 trillion or more; exerting great environmental impacts or having the latent possibility of exerting serious environmental impacts, including nuclear power plants; using land requiring change of use purpose of land of a national park; a nature reserve; and a protected landscape area (Tuong, 2014).

The public investment activities must assure publicity and transparency (Anh, 2014). The following are also very important for public investment management: management of the use of public investment funds according to regulations applicable to each funding source; assurance of concentrated, synchronous, quality, efficient, effective investment and resource balancing capability; avoidance of losses and waste; conformity with national socio-economic development strategy and five-year socio-economic development plans; and socio-economic development and sectorial development master plans (Jake, 2015).

\section{Overview of the Content of Vietnam Public Investment Law}

\section{Investment in Public Sectors and Rules of Public Investment Management}

Investment in public sectors. There are four kinds of investments detailed in this paper as follows:

(1) Investment in socio-economic infrastructure programs and projects;

(2) Investment in ancillary facilities for regulatory agencies, public service providers, political institutions, and socio-political organizations;

(3) Investment and assistance in public product and service supply activities;

(4) Governmental investment in projects to be executed in the form of public-private partnership.

Rules of public investment management. The public investment management will help to observe legal regulations on the management and use of the budget capital for public investment. It conforms to socio-economic development strategy, five-year socio-economic development plan, socio-economic development planning and sectorial development planning; and exercises proper rights and responsibilities of state management agencies, organizations, and individuals involved in the management and use of the budget capital for public investment (Manes Rossi, Jorge, Jesus, \& Caperchione, 2015). It also manages the use of the budget capital for public investment according to appropriate regulations on each capital source; ensures sufficiency, consistency, cost efficiency, effectiveness, and capability of balancing all relevant resources for public investment activities; avoids any possible loss and mismanagement; ensures the public disclosure and transparency for public investment activities; as well as encourages organizations and individuals to carry out direct investments or investment activities in the form of public-private partnership for socio-economic infrastructural and public utility development projects.

\section{Classification of Public Investment Projects}

Classification methods. Depending on the nature of public investment projects, they are classified into the following two types: (1) construction projects such as new construction, renovation, upgradation, and expansion of existing investment and construction projects, including the procurement of assets, devices, and equipment; and (2) non-construction projects such as: asset procurement; receipt of the disposition of land use right; purchase, repair, and upgradation of equipment and machinery; and other projects that are not subject to regulations specified at Point (1). Besides that, depending on the significance and size of public investment projects, they are classified into national important projects; Group-A, Group-B, and Group-C projects which conform to the regulated criteria (World Bank, 2012). 


\section{Classification Criteria for Public Investment Projects}

Criteria for national important projects. National important projects are independent investment projects or a cluster of closely combined projects which meet one of the five following criteria: (1) using a sum of above VND 10,000 billion as the budget capital for public investment; (2) creating or facing the possibility of causing substantial impacts on the environment, including nuclear power plants or use of a land parcel that requires the conversion of land use purpose such as a national park, a wildlife sanctuary, a protected landscape area, a forest covering an area of above 50 hectares that serves the purpose of scientific research and experiment, a protection forest covering an area of above 500 hectares which is aimed at barricading wind flow, sand, wind wave, and encroaching on the sea as well as protecting the environment, a production forest covering an area of above 1,000 hectares; (3) utilizing a land parcel, covering an area of 500 hectares, which requires the conversion of land use purpose from the land parcel used for wet rice agriculture with more than two crops; (4) migrating and resettling more than 20,000 residents at mountainous regions and more than 50,000 residents at other regions; and (5) other projects that require the application of special regulations and policies, which are subject to the National Assembly's decisions.

Criteria for Group-A projects. The criteria for Group-A projects can be as follows:

(1) Regardless of the total investment, such projects are classified according to the following criteria: projects located in the vicinity of special national sites; projects located at extremely important areas in terms of national defense and security according to legal regulations on national defense and security; national defense and security projects that are characterized as the state secrets; hazardous substance and explosive manufacturing projects; and infrastructural construction projects for industrial, processing, and exporting zones;

(2) Projects financed by the total investment amount of more than VND 2,300 billion and classified by the following sectors: traffic infrastructure, including wharfs at the sea or river, airport, railroads, and national highways; power generation industry; oil and gas extraction; chemical, fertilizer, and cement; mechanical engineering and metallurgy; mineral extraction and processing; and residential construction;

(3) Projects financed by the total investment amount of more than VND 1,500 billion and classified by the following sectors: traffic infrastructure; irrigation; water supply and drainage and technical infrastructure; electrical engineering; communication and electronic device manufacturing; pharmaceutical chemistry; material production; mechanical construction; and post and telecommunications;

(4) Projects financed by the total investment amount of more than VND 2,300 billion and classified by the following sectors: agriculture, forestry, and aquaculture; national park and wildlife sanctuary; technical infrastructure for new urban zones; and industrial sector;

(5) Projects financed by the total investment amount of above VND 800 billion and classified by the following sectors: health care, culture, and education; scientific research, information science, radio, and television broadcasting; treasure; tourism and sport; and civil construction.

Criteria for Group-B projects. There are four types of projects as follows:

(1) Projects classified by the sectors stipulated in the above second item (Criteria for Group-A Projects Section) and financed by the total investment amount ranging from VND 120 billion to below VND 2,300 billion;

(2) Projects classified by the sectors stipulated in the above third item (Criteria for Group-A Projects Section) and financed by the total investment amount ranging from VND 80 billion to below VND 1,500 billion; 
(3) Projects classified by the sectors stipulated in the above fourth item (Criteria for Group-A Projects Section) and financed by the total investment amount ranging from VND 60 billion to below VND 1,000 billion;

(4) Projects classified by the sectors stipulated in the above fifth item (Criteria for Group-A Projects Section) and financed by the total investment amount ranging from VND 5 billion to below VND 800 billion.

Criteria for Group-C projects. There are four types of projects as follows:

(1) Projects classified by the sectors stipulated in the above second item (Criteria for Group-A Projects Section) and financed by the total investment amount ranging below VND 120 billion;

(2) Projects classified by the sectors stipulated in the above third item (Criteria for Group-A Projects Section) and financed by the total investment amount ranging below VND 80 billion;

(3) Projects classified by the sectors stipulated in the above fourth item (Criteria for Group-A Projects Section) and financed by the total investment amount ranging below VND 60 billion;

(4) Projects classified by the sectors stipulated in above fifth item (Criteria for Group-A Projects Section) and financed by the total investment amount ranging below VND 45 billion.

\section{The Articles That have an Effect on Public Sector Accounting in Vietnam}

\section{The Transparency in Investment and Accounting}

Contents that require the public disclosure and transparency in public investment activities are composed of: (1) policies, laws, and the introduction of such policies and laws on the management and use of the budget capital for public investment; (2) principles, criteria, and allotment of the budget capital for public investment activities; (3) principles, criteria, and bases for the determination of project portfolio in mid-term and annual public investment plan; (4) planning, proposal, and program for public investment activities at local areas where project sites are located; allotment of the budget capital for specific public investment programs, which depends much on each fiscal year, progress of execution, and disbursement of project fund; and (5) project portfolio throughout local areas where project sites are located, including size, total investment amount, schedule, and construction site; evaluation report on common effects of such projects on local areas where project sites are located (Naughton \& Spamann, 2015).

\section{The Related Expenses}

Expenses incurred from formulation, appraisal, supervision, monitoring, evaluation, and inspection of public investment plans, programs, and projects are as follows:

(1) Expenses incurred from the formulation and appraisal of report on investment intentions for national target programs or public investment programs funded by allocated expenditures from the state budget granted to the agency and unit in charge of these tasks;

(2) Expenses incurred from the formulation and appraisal of pre-feasibility study report and report on investment intentions, financed by the fund for the preparation of investment projects;

(3) Expenses incurred from the formulation and appraisal of public investment plans funded by allocated expenditures or current expenditures from the state budget granted to the agency or unit in charge of these tasks;

(4) Expenses incurred from the supervision, monitoring, and evaluation of public investment plans, programs, and projects funded by allocated expenditures or current expenditures from the state budget granted to the agency or unit in charge of these tasks; 
(5) Expenses incurred from public investment plans' inspection, programs, or projects funded by current expenditures allocated from the state budget to the agency or unit in charge of this task;

(6) In respect of public investment programs and projects financed by Official Development Assistance (ODA) funds and overseas concessional loans, foreign donors are encouraged to provide financial support to cover these expenses as regulated.

\section{Other Articles' Effect on Vietnamese Accounting}

State budget concerns the monetary fund of a country and is considered as a tool of macro adjustments for social economic development and production, regulates the market, and promotes market valorization. Besides the positive results of revenue and expenditure, there are also some difficulties and challenges. Vietnam needs to have effective methods to manage the revenue and expenditure process from the state budget, and the government has used the accounting system of state budget revenues and expenditure to implement this.

Table 1

Comparison of Three Aspects Between Vietnam Public Investment Law and Public Accounting Law

\begin{tabular}{|c|c|c|}
\hline Item & Regulated in Law 2015 & To accounting regime \\
\hline $\begin{array}{l}\text { Subjects } \\
\text { controlled by } \\
\text { law }\end{array}$ & $\begin{array}{l}\text { Public investment includes investment in } \\
\text { socio-economic infrastructure programs and projects; } \\
\text { investment serving activities of state agencies, } \\
\text { non-business units, political organizations, and } \\
\text { socio-political organizations; investment in support } \\
\text { of the provision of public products and services; and } \\
\text { state investment in public-private partnership } \\
\text { projects. }\end{array}$ & $\begin{array}{l}\text { The same as subjects, such as accountants from } \\
\text { administration and non-production units attending the } \\
\text { training workshop were provided with guidelines } \\
\text { stipulated at the Decision } 19 \text { for the year } 2006 \text { on how to } \\
\text { make accounting treatments for new economic activities } \\
\text { that have arisen and will arise. }\end{array}$ \\
\hline Budgets & $\begin{array}{l}\text { Public investment funds include funds from the state } \\
\text { budget, funds from national and government bonds } \\
\text { and municipal bonds, official development assistance } \\
\text { loans, concessional loans of foreign donors, state } \\
\text { development investment credit, retained revenues for } \\
\text { investment not yet included in the state budget } \\
\text { balance, and other loans borrowed by local budgets } \\
\text { for investment purposes (Raudla \& Tammel, 2015). }\end{array}$ & $\begin{array}{l}\text { Including accounting for receiving and using funds at } \\
\text { non-production units which follow the financial } \\
\text { autonomy mechanism and at state agencies which follow } \\
\text { mechanism on autonomy and self-responsibility for } \\
\text { using permanent staff and administrative expenditures; } \\
\text { accounting for production and business activities; tax } \\
\text { accounting with breakdown of each tax line at units } \\
\text { engaging in production and business activities and } \\
\text { agencies implementing assistance projects and enjoying } \\
\text { VAT refund, business income tax accounting. }\end{array}$ \\
\hline $\begin{array}{l}\text { Timing for } \\
\text { preparation of } \\
\text { project and } \\
\text { planning }\end{array}$ & $\begin{array}{l}\text { Stipulation on investment planning, which should be } \\
\text { made on a five-year basis instead of annual plans in } \\
\text { the past. The move is in accordance with the } \\
\text { country's five-year socio-economic development } \\
\text { plans, which will facilitate the allocation of } \\
\text { investment resources and help ministries and } \\
\text { localities make suitable investment decision; } \\
\text { maximize the efficiency of public investment, } \\
\text { especially amid limited capital sources, and to } \\
\text { facilitate a transparent use of the state and local } \\
\text { budget, admitting that other overall measures are } \\
\text { needed in conjunction to optimize public investment. }\end{array}$ & $\begin{array}{l}\text { Financial statements of accounting units engaged in state } \\
\text { budget revenue and expenditure activities shall be made } \\
\text { at the end of monthly, quarterly, and annual accounting } \\
\text { periods. Financial statements of administrative or } \\
\text { non-business accounting units or organizations using the } \\
\text { state budget shall be made at the end of the quarterly and } \\
\text { annual accounting periods. } \\
\text { The budget settlement reports of accounting units } \\
\text { engaged in state budget revenue and expenditure } \\
\text { activities shall be the revised financial statements of the } \\
\text { annual accounting periods. }\end{array}$ \\
\hline
\end{tabular}

Vietnam revenues and expenditures accounting has brought useful information for the users. However, the recognition of revenues and expenditure from the budget is implemented by many agencies with different purposes, methods, objects, and contents of budget accounting and reporting norms. Consequently, the data on budget revenues and expenditures of the agencies are different and did not meet the requirements for management analysis. Recognizing the limitations, Vietnam needs to have some changes in its regime of 
budget revenue and expenditure accounting and also needs to provide the information about the budget to the international organizations to be able to get the grants, aids, or funds for the national capital. From that, many revenues or expenses are from the investment progress of public sector organization. During the construction or projects, accountants must record revenues or expenses onto the accounting books and they should use law on public investments for reference. Hence, the comparison between the regulation on public investment law and accounting rules is necessary. It will affect the accounting actions during the period of financial year. Table 1 above will describe the differences in some aspects of the two laws for understanding those effects.

\section{Conclusion}

The 2015 Law on Public Investment can be considered a revolution in the management of public investment. The law provides a consistent legal framework for the management and use of public investment resources and for overcoming the constraints created by the previous public investment law. The new law has some strengths, including preventing entities from making casual, subjective decisions. As we all know, public investment uses taxpayers' money. So, investment regulations must be tight and strict and should follow the prescribed administrative procedures. For example, the first chapter of the law covers the rights and obligations of government agencies and offices, particularly individuals engaged in public investment projects. Another progressive point in the 2015 law is that it will help eliminate the problem of fragmented, wasteful, and delayed completion of projects. The law also gives specific procedures for all projects. The law also emphasizes a pre-requisite in which entities must have money available to implement the project and show the project's priority level as it is prescribed in the public investment law. People are confident that if all ministries, sectors, and localities strictly abide by the law, public investment projects will be implemented efficiently and successfully. The development of a mid-term investment plan will enable ministries, sectors, and localities to be proactive in developing their plans for accounting activities, with the objective of creating strong links between public investment plans and other socio-economic development plans in the next five years. This is a good and progressive model that helps accountants use our limited resources efficiently.

\section{References}

Anh, M. (2014, June 4). Effectiveness of public investment law. Vietnam Business Forum Magazine. Vietnam Chamber of Commerce and Industry, Vietnam.

Jake, M. (2015, January 24). Investment law tackles corruption. Viet Nam News.

Manes Rossi, F., Jorge, S., Jesus, M. A., \& Caperchione, E. (2015). Introduction to a symposium on new challenges for public-sector accounting: IPSAS, budgetary reporting, and national accounts. International Journal of Public Administration, 38(4), 237-239.

Naughton, J. P., \& Spamann, H. (2015). Fixing public sector finances: The accounting and reporting lever. UCLA Law Review, 62(3), 572-620.

Nguyen, M. P. (2012). Improving efficiency of public investment in Viet Nam. Communist Review.

Pham, T. T. (2013, September 24). Lawmakers agree to issue law on public investment. Viet Nam News.

Quang, D. (2014, June 18). NA approves revised law on public investment. Vietnam Investment Review.

Raudla, R., \& Tammel, K. (2015). Creating shared service centres for public sector accounting. Accounting, Auditing, and Accountability Journal, 28(2), 158-179.

Tuong, T. (2014, February 27). Vietnam seeking to make law on public investment. Vietnam Investment Review.

Vietnam News Agency. (2015). New law on public investment. Vietnam Law and Legal Forum Magazine.

World Bank. (2012). Planning reform in Vietnam: Improving public investment management and service delivery. Vietnam Development Report. 